\title{
Chronic Hepatitis C Treatment-Related Skin Rash: A Report of Two Cases
}

\author{
Kronik Hepatit C Tedavisi Kaynaklı Deri Döküntüsü: Iki Olgu Sunumu
}

\author{
Tuğba ARSLAN GÜLEN, Ayfer IMRE \\ Niğde State Hospital, Clinic of Infectious Diseases and Clinical Microbiology, Niğde, Turkey
}

\section{ABSTRACT}

Pegylated interferon alpha and ribavirin are used as combination therapy in chronic hepatitis C treatment and may cause various cutaneous reactions. Some skin rashes improve with oral antihistamines and topical therapy, whereas others need to discontinue the treatment. In this report, we present two patients who developed skin reactions during anti-HCV treatment; one of the patients recovered without interrupting therapy.

Key Words: Chronic hepatitis C, ribavirin, pegylated interferon alpha, skin rash

\section{ÖZET}

Pegile interferon alfa ve ribavirin, kronik hepatit $\mathrm{C}$ tedavisinde kullanılan kombinasyon tedavisi olup, çeşitli kutanöz reaksiyonlara neden olabilmektedir. Deri lezyonlarının bir kısmı oral antihistaminik ve topikal tedavi ile düzelme gösterirken, diğer bir kısmında tedaviye ara vermek gerekmektedir. Bu raporda, hepatit $\mathrm{C}$ tedavisi sırasında deri döküntüsü gelişen ve birinde tedaviye ara vermeksizin düzelme görülen iki hasta sunulmuştur.

Anahtar Kelimeler: Kronik hepatit C, ribavirin, pegile interferon alfa, deri döküntüsü

\section{Introduction}

Pegylated interferon (PEG-IFN) alpha and ribavirin are used as combination therapy in chronic hepatitis $\mathrm{C}$ virus ( $\mathrm{HCV}$ ) infection, and cutaneous reactions associated with the disease and therapy can be seen. The most common cutaneous side effects due to IFN alpha therapy are localized infections at the injection site and localized allergic reactions. Other side effects, including lichen planus, psoriasis, vitiligo, xerosis, and eczematous reactions have been reported. Adverse events associated with combination therapy vary from generalized pruritus and xerosis to erythematous papules and excoriated microvesicles $(1,2)$. In this study, we aimed to present two patients who developed skin reactions during PEGIFN alpha/ribavirin therapy.

\section{Cases}

\section{Case 1}

A 48-year-old man, who had genotype $4 \mathrm{HCV}$ infection with a viral load of $461000 \mathrm{IU} / \mathrm{mL}$, was started PEG-IFN alpha 2a 180 $\mathrm{mcg} /$ week and ribavirin $1200 \mathrm{mg} /$ day as combination therapy in
April 2014. On the $10^{\text {th }}$ week of treatment, the patient developed skin eruptions. The lesions were diffuse, pruritic, confluent, papular and erythematous, especially on the trunk and upper extremities away from the injection sites (Figure 1, and 2). We started the patient on antihistamines and topical steroid primarily; after seven days, we suspended ribavirin therapy because of patient discomfort due to severe rashes and we continued antihistamines and topical therapy. After four days, we started ribavirin therapy again. Because of repeat of the rashes, the patient discontinued ribavirin for seven days. After the rash reasonably controlled, we started ribavirin therapy again and the patient tolerated the therapy without reappearance of any skin reactions.

\section{Case 2}

A 42-year-old woman with HCV infection was followed up for 11 years. The patient had genotype $1 \mathrm{~b} \mathrm{HCV}$ infection with a viral load of $6.33 \times 10^{5} \mathrm{IU} / \mathrm{ml}$, while we started peg-IFN alpha2a $180 \mathrm{mcg} /$ week and ribavirin $1000 \mathrm{mg} /$ day in July 2013. On the 7 th month of therapy, patient developed pruritic, confluent, maculopapular skin lesions on erythematous ground, away from the injection sites (Figure 3,4). Topical steroid treatment was 


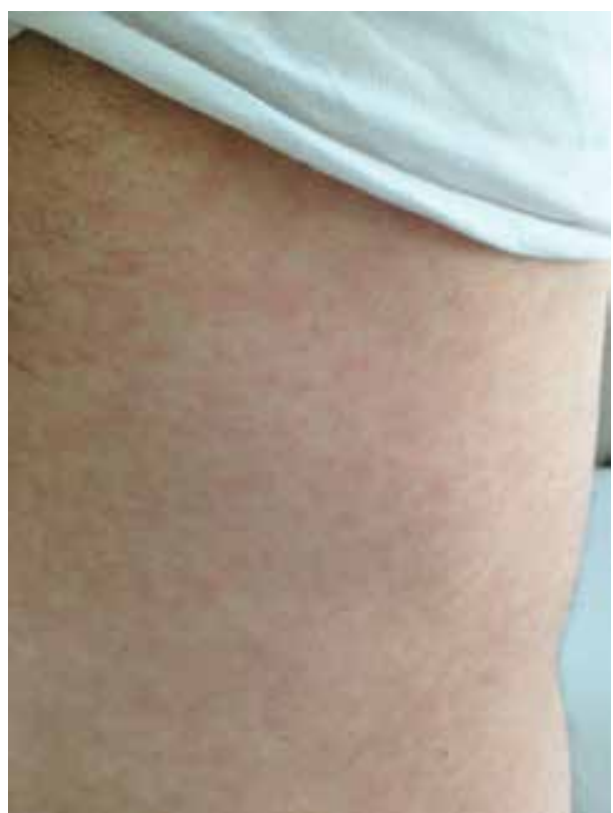

Figure 1. Diffuse, confluent, erytematous skin lesions on the trunk of patient described in case 1

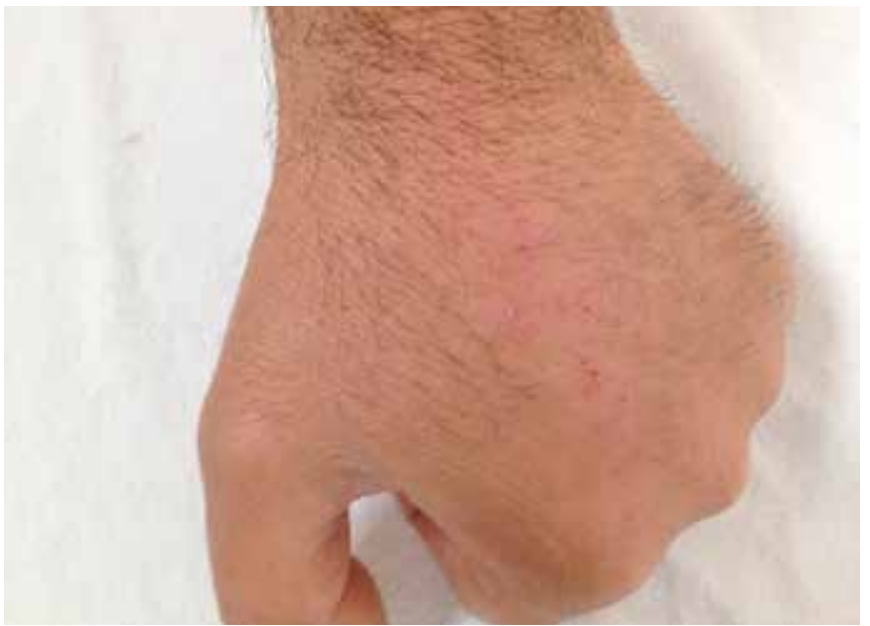

Figure 2. Pruritic lesions on erytematous ground on the upper extremity

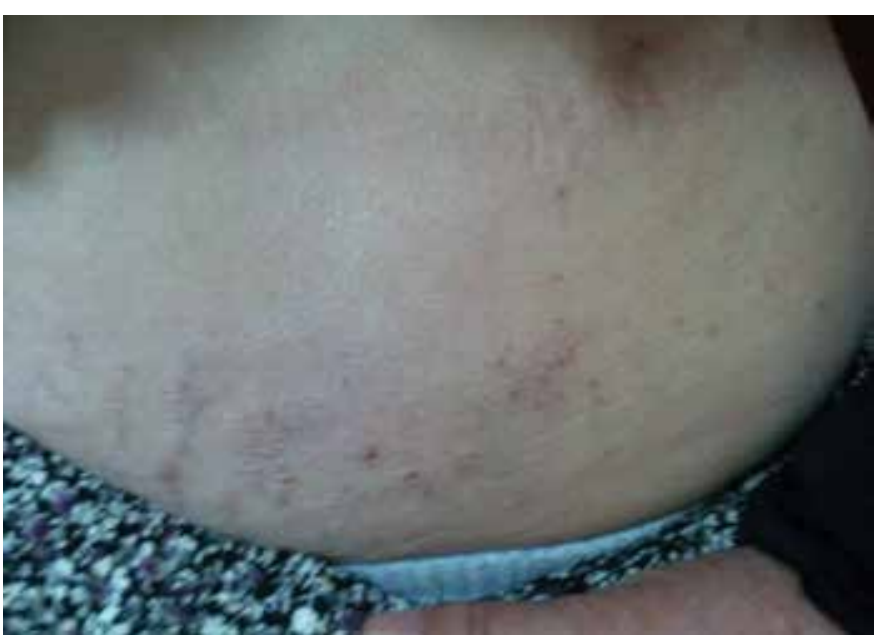

Figure 3. Pruritic, maculopapular skin lesions on the batın of case 2

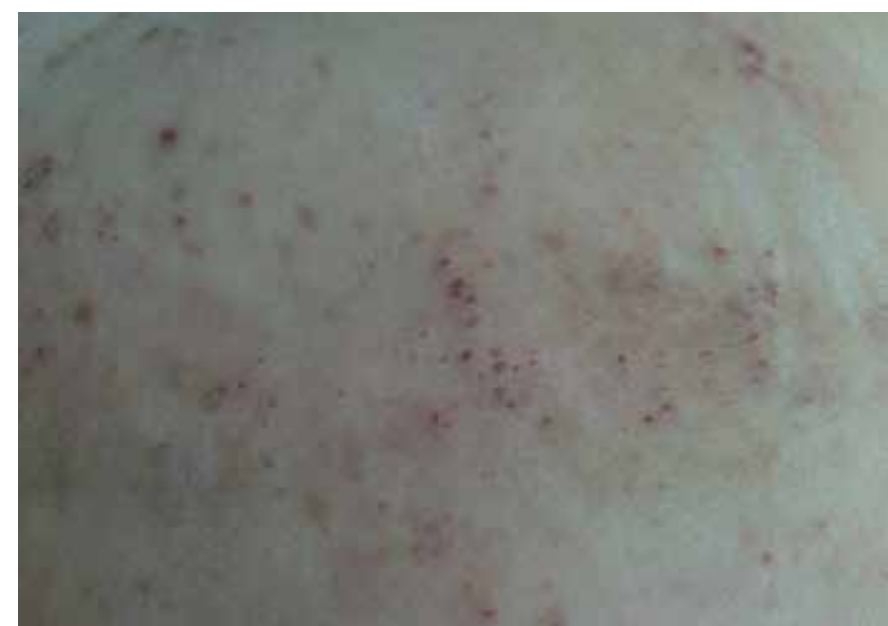

Figure 4. Pruritic, maculopapular skin lesions in case 2

started. With this topical treatment, skin lesions were resolved without requiring discontinuation of anti-HCV treatment.

\section{Discussion}

Different types of dermatologic manifestations are seen during both HCV infection and anti-HCV therapy. The incidence of skin lesions due to anti-HCV therapy is $21-28 \%$ according to randomized controlled clinical trials (3). Skin lesions vary from localized erythema to diffuse skin involvement. In the literature, there are many case reports describing skin reactions due to anti-HCV treatment. In some of these cases, skin reactions have recovered after discontinuation of therapy as in our first case $(4,5,6,7)$. Veluru and colleagues reported three cases initially treated with PEG-IFN alpha and ribavirin and developed skin reactions during therapy. In three cases, skin reactions had recovered after discontinuation of ribavirin, and in one of the cases, oral antihistamines were used additionally as in our case (7). In the previously reported studies, it is not clear whether skin reactions were due to IFN or ribavirin. In the first case, it is considered that skin lesions could be related to ribavirin therapy, because skin reactions resolved after discontinuation of ribavirin. Sookoian and colleagues studied 68 patients who were given anti-HCV therapy, 33 of 68 patients received IFN and ribavirin, and the rest received only IFN therapy. Cutaneous reactions were significantly more common in patients receiving combination therapy (33.4-5.7\%) (8). This reason gives rise to thought that skin eruptions might be seen more frequent due to ribavirin. In some of the studies, skin lesions were resolved without discontinuation of therapy in the majority of patients $(9,10,11)$. In one of these studies performed by Patrk and colleagues, it is pointed that the number of patients followed without discontinuation of therapy was less than the number of those continued therapy (9). In our second case, skin lesions recovered without discontinuation of anti-HCV treatment and with using symptomatic treatment, including antihistamines and topical steroid.

In conclusion, it is unclear whether IFN or ribavirin is the contributing factor for skin reactions. It is very important to maintain anti-HCV treatment for response to therapy; because of that depending on severity of the skin lesions, topical therapies as steroids and antihistamines can be used instead of discontinuing 
ribavirin. If skin lesions worsen despite these medications, we recommend discontinuing ribavirin until the rash resolves and then resuming ribavirin.

Informed Consent: Consent form was filled out by all participants, Concept: Tuğba Arslan Gülen, Design: Tuğba Arslan Gülen, Data Collection or Processing: Tuğba Arslan Gülen, Ayfer Imre, Analysis or Interpretation: Tuğba Arslan Gülen, Ayfer Imre, Literature Search: Tuğba Arslan Gülen, Writing: Tuğba Arslan Gülen, Peer-review: Externally peer-reviewed, Conflict of Interest: No conflict of interest was declared by the authors, Financial Disclosure: The authors declared that this study has received no financial support.

\section{References}

1. Cacoub P, BourliEre M, Lübbe J, Dupin N, Buggisch P, Dusheiko G, HEzode C, Picard O, Pujol R, Segaert S, Thio B, Roujeau JC. Dermatological side effects of hepatitis $C$ and its treatment: Patient management in the era of direct-acting antivirals. $\mathrm{J}$ of Hepatol. 2012; 56: 455-463.

2. Gurbuz Y, Tutuncu EE, Ozturk DB, Baylak A, Sencan I. Kronik Hepatit $C$ tedavisini takiben gelişen cilt bulgularl; iki olgu sunumu. Viral Hepatit Derg. 2011; 17: 84-87.

3. Lübbe J. Dermatological side effects. Hot Topics in Vira Hepatitis. 2008; 9: 29-35.
4. Moore MM, Elpern DJ, Carter DJ. Severe, generalized nummular eczema secondary to interferon alpha-2b plus ribavirin combination therapy in a patient with chronic hepatitis $\mathrm{C}$ virus infection. Arch Dermatol. 2004; 140: 215-217.

5. Hashimoto $Y$, Kanto $H$, Itoh $M$. Adverse skin reactions due to pegylated interferon alpha $2 \mathrm{~b}$ plus ribavirin combination therapy in a patient with chronic hepatitis C virus. J Dermatol 2007; 34: 577-582.

6. Toney RC, Agrawal Rad M, Loeffert M. Injection site bullous eruption and generalized rash induced by pegylated interferon treatment for hepatitis C. Gastroenterol Hepatol. 2009; 5: 715-719.

7. Veluru C, Atluri D, Chadalavada R, Burns E, Mullen DK. Skin rash during chronic hepatitis C therapy. Gastroenterol Hepatol. 2010; 6: 323-325

8. Sookoian S, Neglia V, Castaño G, Frider B, Kien MC, Chohuela E. High prevalence of cutaneous reactions to interferon alpha plus ribavirin combination therapy in patients with chronic hepatitis C virus. ArchDermatol. 1999; 135: 1000-1001.

9. Patrk I, Morovie M, Markulin A, Patrk J. Cutaneous reactions in patients with chronic hepatitis $C$ treated with peginterferon and ribavirin. Dermatology. 2014; 228: 42-46.

10. Dereure O, Raison-Peyron N, Larrey D, Blanc F, Guilhou JJ. Diffuse inflammatory lesions in patients treated with interferon alfa and ribavirin for hepatitis $\mathrm{C}$ : a series of 20 patients. $\mathrm{Br} \mathrm{J}$ Dermatol. 2002; 147: 1142-1146.

11. Basaranoglu M, Celebi S, Karaaslan H, Demir A. Case study on drug-related adverse effects of hepatitis $C$ therapy. Adv Ther. 2006; 23: 769-771. 